\title{
Where Will the World's Poor Live? An Update on Global Poverty and the New Bottom Billion
}

\section{Andy Sumner}

\begin{abstract}
This paper updates the distribution of global poverty data and makes projections up to 2020 . The paper asks the following question: Do the world's extreme poor live in poor countries? It is argued that many of the world's extreme poor already live in countries where the total cost of ending extreme poverty is not prohibitively high as a percentage of GDP. And in the not-too-distant future, most of the world's poor will live in countries that do have the domestic financial scope to end at least extreme poverty. This would imply a reframing of global poverty as largely a matter of domestic distribution.
\end{abstract}

JEL Codes: I32

Keywords: poverty, inequality, distribution, low-income countries, middle-income countries. 


\title{
Where Will the World's Poor Live? An Update on Global Poverty and the New Bottom Billion
}

\author{
Andy Sumner \\ King's International Development Institute \\ King's College London
}

This paper was previously published as two IDS working papers. Special thanks to Pui Yan Wong and Henrique Conca Bussacos for research assistance. Many thanks to two anonymous peer reviewers and Xavier Cirera, Jeni Klugman, Ben Leo, David Steven, and Amy Pollard for feedback on earlier drafts. Correspondence to andrew.sumner@kcl.ac.uk

CGD is grateful for contributions from the Norwegian Ministry of Foreign Affairs, the Swedish Ministry of Foreign Affairs, and the William and Flora Hewlett Foundation in support of this work.

Andy Sumner . 2012. “Where Will the World's Poor Live.” CGD Working Paper 305.

Washington, D.C.: Center for Global Development.

http://www.cgdev.org/content/publications/detail/1426481

Center for Global Development 1800 Massachusetts Ave., NW Washington, DC 20036

202.416 .4000

(f) 202.416 .4050

www.cgdev.org
The Center for Global Development is an independent, nonprofit policy research organization dedicated to reducing global poverty and inequality and to making globalization work for the poor. Use and dissemination of this Working Paper is encouraged; however, reproduced copies may not be used for commercial purposes. Further usage is permitted under the terms of the Creative Commons License.

The views expressed in CGD Working Papers are those of the authors and should not be attributed to the board of directors or funders of the Center for Global Development. 


\section{Introduction}

The majority of the world's poor, by income and multi-dimensional poverty measures, live in countries classified by the World Bank as middle-income countries (Alkire et al., 2011; Chandy \& Gertz, 2011; Glassman et al., 2011; Kanbur \& Sumner, 2011; Sumner, 2010; 2012).

Such patterns matter beyond the thresholds for low-income countries and middle-income countries (LICs/MICs) set by the World Bank, because they reflect a pattern of rising average incomes and although the thresholds do not mean a sudden change in countries when a line is crossed in per capita income, substantially higher levels of average per capita income imply substantially more domestic resources available for poverty reduction.

Further, the changing distribution of global poverty away from the poorest countries (however defined), suggests an apparent "poverty paradox" - that most of the world's extreme poor do not live in the world's poorest countries.

One interpretation of the shift in global poverty is that extreme poverty is gradually changing from a question of poor people in absolute poor countries to questions about domestic inequality. This paper explores this.

The paper is structured as follows: Section 2 briefly reprises, with updated data, the distribution of global poverty. Section 3 discusses concepts of absolute and relative "poor" countries to assess if middle-income countries are "poor" and, if so, in what sense. Section 4 and 5 focuses on questions related to inequality. Section 6 concludes.

\section{The Distribution of Global Poverty}

The following discussion updates the global poverty distribution data in Sumner (2010; 2012), based on a significantly updated dataset (World Bank, 2012); and extends analysis to the $\$ 2$ poverty line. The data produced is consistent with the new global and regional estimates of Chen and Ravallion (2012).

It is worth noting at the outset that there are a range of methodological questions about the use of poverty lines per se (see for review Fischer, 2010), and the international poverty lines in particular, most notably the use of PPPs (see for most recent discussion, Deaton, 2010; 2011; Deaton \& Heston, 2010; Klasen, 2010). The outcome of such debates are summed up by Deaton (2010, p. 31) who concludes the data are "good enough" to support poverty counts, although uncertainties should be recognised. 
In light of these points and in terms of assessments of robustness it is reassuring that the distribution of global poverty by income poverty is consistent with the global distribution, overall, of multi-dimensional poverty (Alkire et al. 2011), as well as healthrelated poverty (Glassman et al. 2011); and the estimates of global distribution of income poverty have been corroborated by Chandy and Gertz (2011).

Further, the data coverage of the new PovcalNet (World Bank, 2012) covers 84 percent of the population of LICs and 98 percent of the population of MICs in 2008. The only missing countries with populations of more than 10 million people are: Afghanistan (29m population in 2008), North Korea (23m population in 2008), Myanmar (49m population in 2008), Uzbekistan (27m population in 2008), Zimbabwe (12m in 2008), and Cuba (10m in 2008). Argentina (total population $39 \mathrm{~m}$ in 2008) is not included here as it has only urban poverty data in PovcalNet (World Bank, 2012).

New estimates for global poverty in 2008 support earlier findings that most of the world's poor (by both $\$ 1.25$ and $\$ 2$ international poverty lines) live in South Asia and subSaharan Africa. In contrast, in 1990 half of the world's poor lived in East Asia and the Pacific, mostly in China (see Chen \& Ravallion, 2008; 2012).

The proportion of the world's $\$ 1.25$ poor in China fell to an estimated 14 percent in 2008, while India's proportion of world poverty rose to 35 percent, and sub-Saharan Africa's to 31 percent (see Table 1 and 2 at the end of the document). The $\$ 2$ estimates - the average poverty line for developing countries - present a similar pattern to the $\$ 1.25$ estimates, with a notably lower contribution to world poverty from sub-Saharan Africa.

Estimates for 2008 also confirm that the world's poor (by both $\$ 1.25$ and $\$ 2$ poverty lines) largely live in middle-income countries (MICs), albeit lower middle-income countries (LMICs). The proportion of the world's \$1.25 and \$2 poor accounted for by MICs is, respectively, 74 percent and 79 percent. This suggests that using the average poverty line for developing countries means that even more of the world's poor live in MICs. Indeed, closer analysis suggests a billion extreme poor, and a further billion people between \$1.25 and \$2/day per capita, live in MICs (see below).

In spite of the global distribution of poverty, it is important of course to note that LICs typically have higher rates of poverty incidence (see Table 1) and a larger poverty gap. Thus any discussion of poverty in MICs should not distract from poverty in the remaining LICs.

That said, some MICs do have surprisingly high poverty headcounts (and a higher than expected poverty gap), even at the higher average level of per capita income found in MICs. Across all MICs, the average (population weighted) incidence of poverty is almost one in five of the population at $\$ 1.25 /$ day, and 40 percent at $\$ 2 /$ day. In the LMICs, this rises to 30 percent and 60 percent respectively (although without India this falls respectively to 25 percent and 50 percent in the LMIC group). 
Importantly, the shift from the $\$ 1.25$ poverty line to the $\$ 2$ poverty line doubles the poor in MICs from almost $1 \mathrm{bn}$ to almost $2 \mathrm{bn}$ (meaning there are a billion people under $\$ 1.25$ in MICs and another billion between $\$ 1.25$ and $\$ 2$ in MICs). In contrast, the shift from $\$ 1.25$ to $\$ 2$ in LICs raises the total number of people in poverty by a considerably smaller amount (from $320 \mathrm{~m}$ to $490 \mathrm{~m}$ ).

In sum, the distribution of global poverty is thus: Half of the world's poor live in India and China (mainly in India); A quarter of the world's poor live in other MICs (primarily populous LMICs such as Pakistan, Nigeria and Indonesia); and a quarter (or less) of the world's poor live in the remaining LICs.

There is an important question of how sensitive the changes in the distribution of global poverty are to the LIC/MIC thresholds. The two figures below (Figures 1 and 2) show the cumulative poverty counts by GNI per capita (Atlas - used to produce the country thresholds and categorise countries) with LIC/LMIC/UMIC thresholds identified. 44 percent of the world's poor live in India and Nigeria; countries that are about 20 percent above the $\$ 1005$ threshold. The shift in the global distribution of poverty from LICs to MICs is thus, of course, a function of the thresholds themselves; but the bulk of world poverty is well above the current $\$ 1005$ per capita LIC threshold.

Such an assessment is, however, based on a methodological mismatch - the mismatch between the Atlas (exchange rate conversion) method used to construct the "poor countries" threshold (meaning the LIC/MIC threshold), and the PPPs method used to construct the "poor people" threshold (meaning the international poverty lines). Thus to assess more systematically how sensitive estimates of global poverty are to thresholds, one approach that can be taken is to produce cumulative poverty counts for $\$ 1.25$ poverty, and plot against GDP PPP per capita at multiples of the $\$ 1.25$ poverty line (see Figures 3 and 4). Indeed, one way one could think about absolute and relative "poor" countries is by applying the international poverty line - $\$ 1.25 /$ day (or $\$ 2 /$ day) - for individuals, and multiples of them, to each country's average income (see later discussion). ${ }^{1}$ However, such an approach is open to the criticism that it simply replaces one set of arbitrary thresholds with another set, albeit a set that logically links definitions of poverty.

\footnotetext{
${ }^{1} \$ 1.25 /$ day is the mean of the national poverty lines of the poorest 15 countries in terms of consumption per capita, and \$2/day is the median poverty line for all developing countries (Chen \& Ravallion, 2008: p. 4).
} 
Figure 1

Global poverty, US\$1.25, by GNI per capita, Atlas, 2008/9

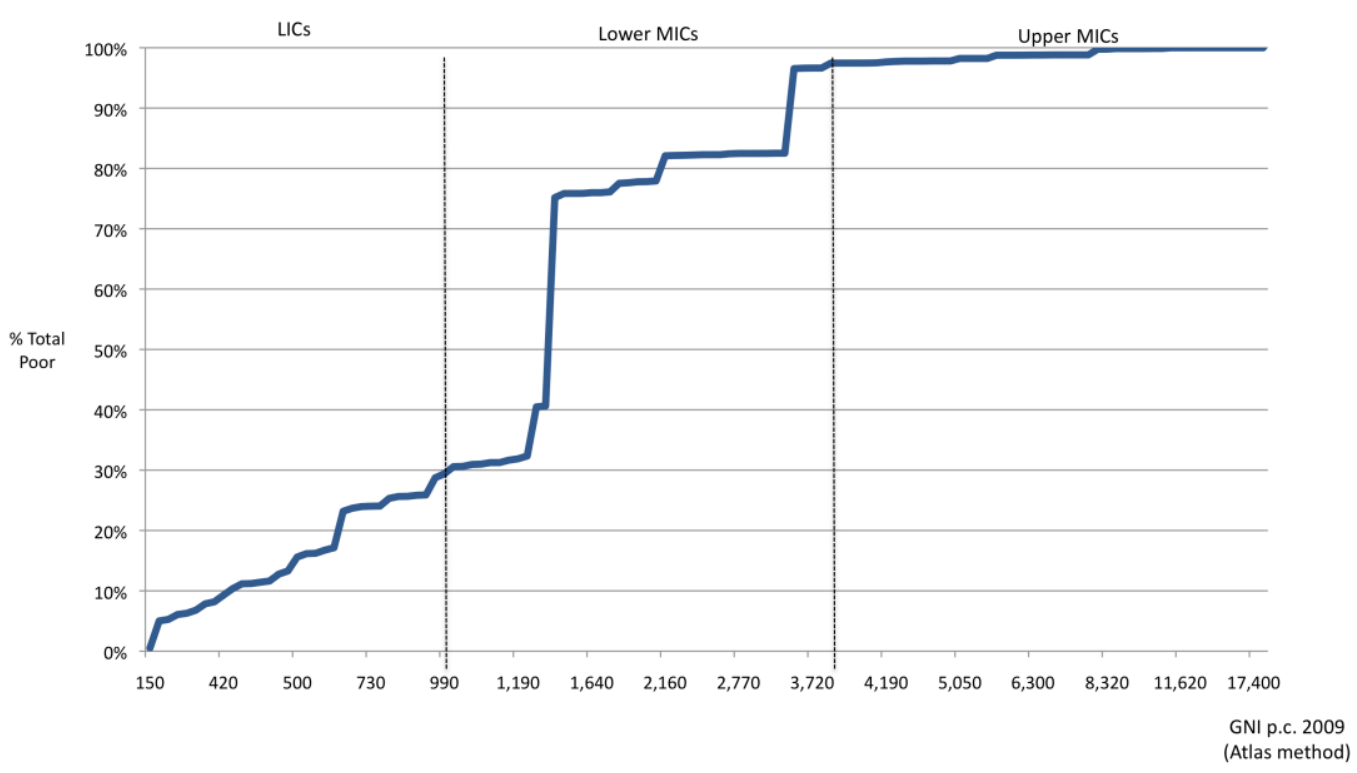

Figure 2

Global poverty, US\$2, by GNI per capita, Atlas, 2008/9

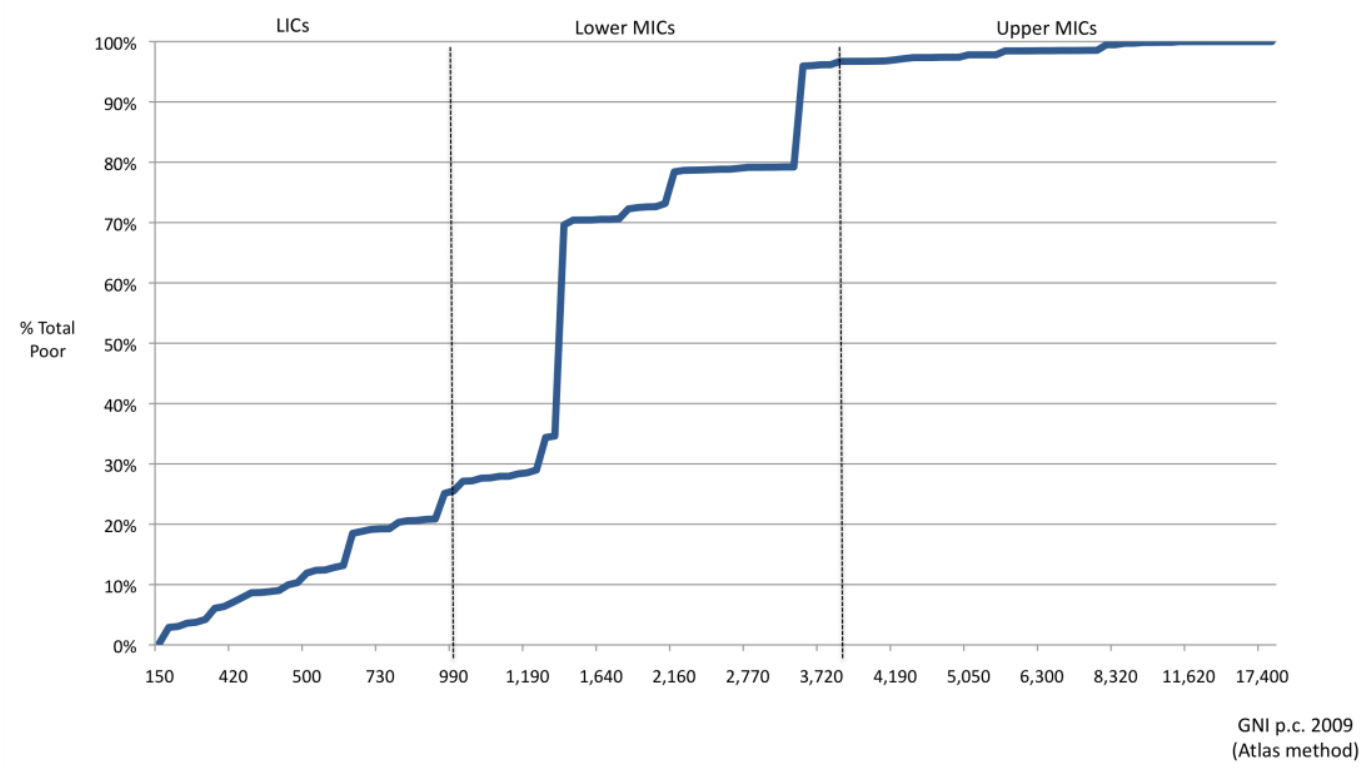


Figure 3

Global poverty, $\$ 1.25$, by GDP pc, PPP, 1990 vs 2008/9

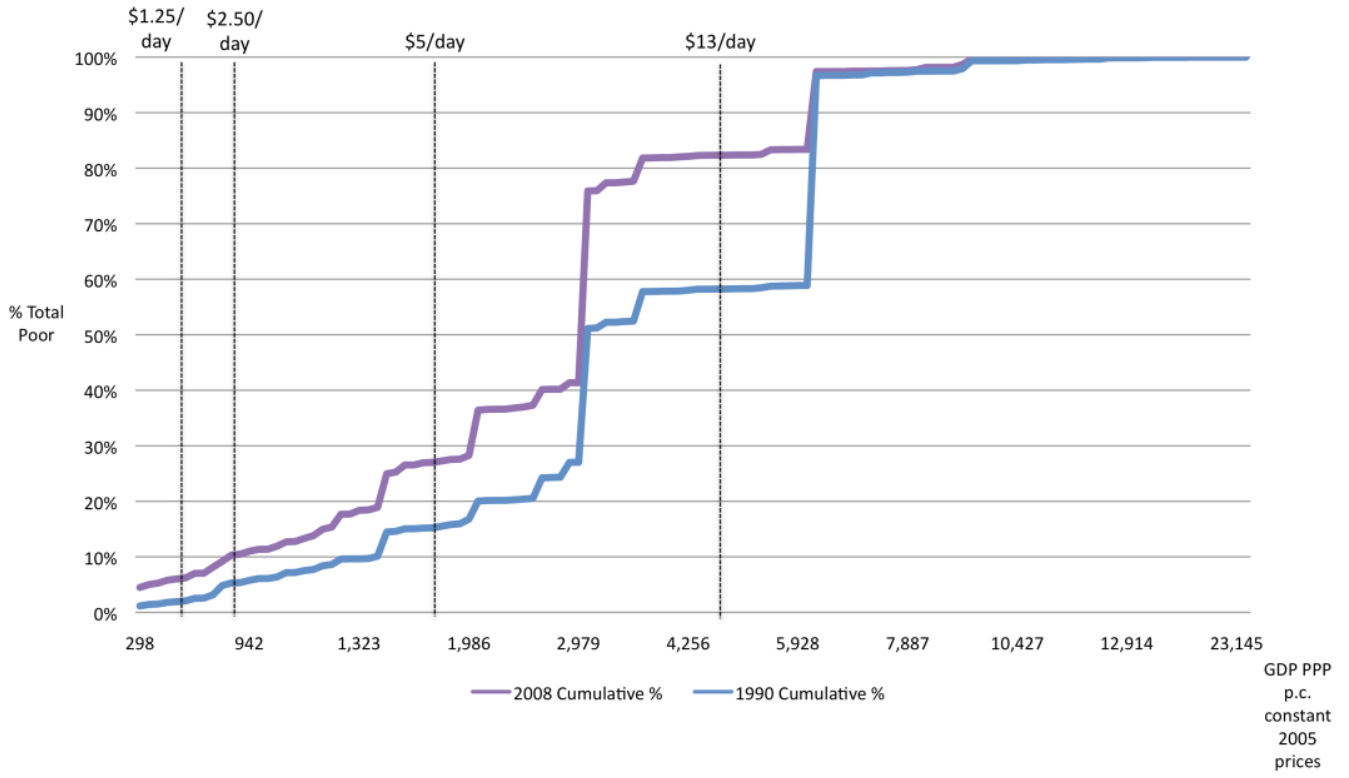

Figure 4

Global poverty, \$2, by GDP pc, PPP, 1990 vs 2008/9

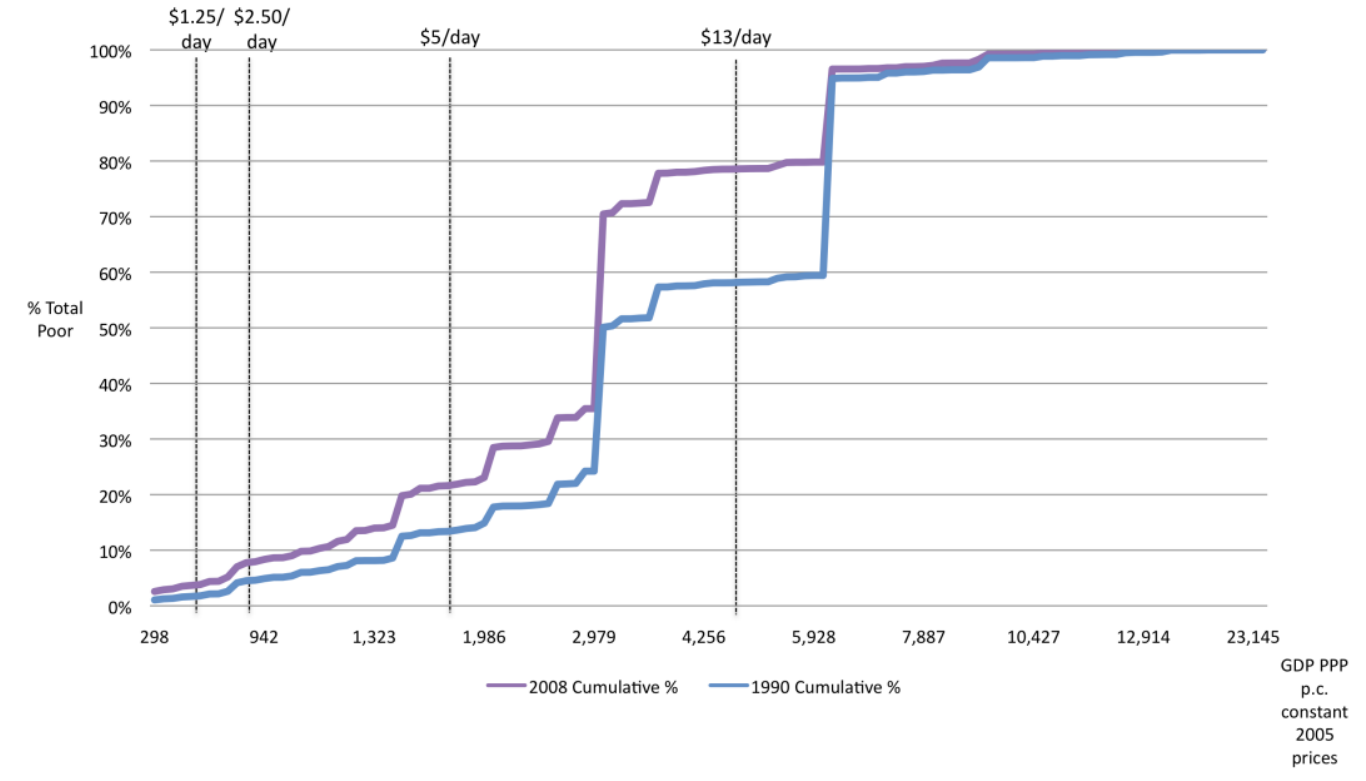


An alternative is analysis of the countries in each quartile of GDP PPP per capita (2005 constant \$) in 1990 and 2008/9. The changing distribution of world poverty by quartiles produces interesting results (see Tables 3 and 4). Of course, this is a relative comparison in contrast to an absolute comparison of country thresholds. What is evident is that the vast majority of countries are in exactly the same quartile by GDP PPP per capita in 2008 as they are in 1990, with the exception of 16 countries that have risen to higher quartiles by GDP per capita PPP. Taking GDP PPP per capita, in 1990 almost 90 percent of the world's poor lived in the poorest quartile of countries. In contrast, in 2008, only a third of the world's poor were in the poorest quartile and two-thirds were in the quartile above the poorest quartile (Q2). However, four-fifths of the world's poor in Q2 GDP PPP per capita in 2008 were accounted for by India and China. The remainder relate both to countries rising from Q1 to Q2: notably populous Pakistan and Vietnam (and Bhutan, Cape Verde and Guyana); and populous countries already in Q2 such as Indonesia.

Clearly, there is much more to investigate here in terms of explanatory factors. One could look closely at population growth rates in the poorest expenditure groups, and what has happened in the channels whereby economic development could lead to poverty reduction (e.g. wage employment, real wages, self-employment and productivity in selfemployment, and the output elasticity of demand for labour).

Interestingly, for those new MICs with two data points there are some drastic changes away from agriculture value added as a proportion of GDP. For example, the proportion of agriculture value added as a percent of GDP drastically fell in Ghana, India, Laos, Lesotho, Vietnam and Yemen.

At a minimum, the fact that poverty persists at higher levels of average per capita income raises questions about the types of economic growth that lead some countries to reduce the number of people in extreme poverty and other countries not to. Most studies have argued that growth is good for the poor in the general sense that the income of the poor rises one-for-one in line with average income (Dollar and Kraay, 2002; Gallup et al., 1999; Roemer \& Gugerty, 1997), and the poverty headcount ratio declines significantly with growth (Bruno et al., 1998; Ravallion, 2001). While it has been strongly asserted that, on average, growth is matched by proportionate reductions in poverty, some evidence challenges this view; suggesting rather that the incomes of the poorest may increase less than proportionately with growth (Besley \& Cord, 2007; Grimm et al., 2007). Importantly, the averages hide large variations across countries and across measures of poverty, both questioning the relevance of the global average and whether growth responds differently to different kinds of (chronic and transient) income poverty. Initial inequality has most commonly been identified as deterministic in the heterogeneity of country experience: a higher level of inequality leads to less poverty reduction at a given level of growth (Deininger \& Squire, 1998; Kraay, 2004; Ravallion, 2001, 2007; Son \& Kakwani, 2003). The heterogeneity of country experience has also been linked to changes in inequality over time, due to geographical differences (urban-rural); the 
sectoral pattern of growth; the composition of public expenditure; labour markets; social capital endowments and the variance in actual rates of growth (Fields, 2001; Kraay, 2004; Mosley, 2004; Mosley et al,. 2004; Ravallion \& Chen, 1997).

\section{Absolute and Relative 'Poor' Countries}

If most of the world's poor live in LMICs, one question that follows is: to what extent are these "poor" countries? Or "poor" countries in relation to what? Dudley Seers (1963) provided the seminal discussion of developed country characteristics, and their divergence from the characteristics of developing countries. On this basis he could justify calling the developed, or industrialised, countries "a special case" of "a few countries with highly unusual, not to say peculiar, characteristics" (p. 80). Seers, (1963: pp. 81-83) identified the characteristic features of the "special case" or advanced economies in "note form" including, for example, factors of production (e.g. literacy and the mobility of labour), sectors of the economy (e.g. manufacturing much larger than either agriculture or mining), public finance (e.g. reliance on direct taxes), households (e.g. very few below subsistence level and a moderately equal distribution of income), savings and investment (e.g. well-developed financial intermediaries), and "dynamic influences" (e.g. slow population growth and high urbanisation).

One could conceptualise "poor" countries in various ways: by absolute measures (meaning thresholds based) and/or relative measures (meaning measures relative to other countries) of absolute poverty and relative poverty at country level (and potential indicative levels for further investigation).

In absolute terms (meaning thresholds) one might conceptualise "poor" or "non-poor" countries in terms of absolute poverty; country-level relative poverty; average incomes compared to the international poverty lines ( $\$ 1.25$ and $\$ 2$ per capita/day); the overall "burden" of poverty (meaning the total poverty gap as a percentage of GDP); or by structural indicators.

One could also think of "poor" countries in relative terms (relative to other countries). For example, by per capita income relative to per capita income in LICs (or LDCs or another grouping); or by overall levels of extreme poverty (percent of population) compared to LICs; or by various structural indicators relative to LICs (e.g. aid dependency, forex reserves, GDP in agriculture or export dependency on primary sectors); or by these structural indicators relative to high-income countries (HICs) of the OECD.

LICs and LMICs can also be compared with three other country groupings related to "poor" countries: the "non-official" group of 45 fragile and conflict affected states (as listed in OECD, 2011b); the UN group of 48 Least Developed Countries; and also the group of 45 countries that are in the poorest quartile of all countries by GDP PPP per capita (see annex Table A1 for population coverage by indicator and group). 
In absolute terms, the group averages for LMICs suggest average per capita PPP income at almost five times the higher international poverty line of $\$ 2$. In relative terms, the average for the LMIC group is considerably higher than the average income of the LIC group - which itself is barely above the higher international poverty line. Overall, levels of extreme poverty as a percentage of population are lower in the LMIC group average compared to the LIC average (see Tables 5 and 6); although, as noted above, they are still surprisingly high in LMICs despite higher average per capita incomes. For comparison, data for Fragile and Conflict-Affected States (FCAS), for Least Developed Countries (LDCs) and for the poorest quartile of all countries by GDP per capita PPP (Q1) are also presented. This discussion is - evidently - overly focused on economic development. One could pursue further dimensions of development such as governance and sustainability, among others.

Even if most of the world's poor live in countries that are not the poorest countries, nor absolutely "poor" countries, nor aid-dependent, the cost of ending poverty may be of a size relative to GDP that means it is unlikely poverty can be fully addressed via domestic resources. In short, one could consider whether countries are "poor" relative to the capacity to end poverty (see discussion in Kanbur \& Mukherjee 2007), expressed as the cost of ending poverty as percentage of GDP. This then estimates the "transfer" necessary as a percentage of GDP from the non-poor to the poor to end poverty.

Using such an approach, absolute and relative poor countries might be estimated by a threshold - with absolute poor countries needing perhaps more than 2 percent of GDP to close the poverty gap, and relative poor countries requiring 1-2 percent, on the basis that the (mean) average for military spending in the combined group of LICs and MICs is 2 percent of GDP (respectively, 1.6 percent in LICs and 2.2 percent in the LMIC group) (population weighted group estimates from data in World Bank, 2011b). This 2 percent level thus gives some crude proxy in the countries where most of the world's extreme poor live for available resources which could be diverted to poverty reduction. Table 7 presents data on the total poverty gap as a percentage of GDP. Data is presented in PPP constant 2005 international dollars to be comparable with later estimates on the poverty gap in 2020.

In the LMICs, the group average for the cost of ending poverty is 1.3 percent of GDP PPP for $\$ 1.25$ poverty, but 5.5 percent for $\$ 2$ poverty (compared to 8.4 percent and 25.4 percent respectively for LICs). However, seventeen MICs have a total poverty gap of greater than 1 percent of GDP (PPP\$, constant 2005 international \$), ranging up to 12.8 percent in Zambia. ${ }^{2}$ When the data for the 20 countries with 90 percent of world poverty are considered, many of the countries which have particularly high costs of ending \$1.25

\footnotetext{
2 The 17 MICs are as follows: Zambia, Nigeria, Lesotho, Timor-Leste, Papua New Guinea, Congo, Rep., Ghana, Angola, Cote d'Ivoire, Lao PDR, Senegal, Swaziland, India, Honduras, Mauritania, Sao Tome and Principe, and Sudan.
} 
(and \$2) poverty as a proportion of GDP are LICs, such as Bangladesh, the DRC, Tanzania, Kenya, Uganda, Mozambique and Malawi. That said, MICs like Nigeria, Angola and Nepal in that list of twenty countries also face high costs of ending poverty (see Table 2).

If most of the world's poor live or will live in the foreseeable future in countries with the domestic financial capacity to end at least extreme poverty, extreme poverty would be a matter of national distribution and domestic political economy (for example, via the redistributive preferences of the middle classes and elites). This would imply the need for a fundamental reframing of global poverty as largely a matter of domestic distribution.

\section{National Inequality and the "Emerging Middle"}

Questions arise relating to domestic distribution in light of the changes in global poverty towards middle-income countries. Notably, what is happening to inequality as average incomes rise? What has happened to inequality in the countries where global poverty is concentrated?

Simon Kuznets $(1955 ; 1963)$ argued, in his presidential address to the 1954 American Economic Association and in later articles, a relationship based on a "hypothetical numerical exercise" of which Kuznets noted 5\% was empirical information and 95\% was speculation. Kuznets postulated an inverted $U$ shape relationship between income and inequality. Kuznets predicted an increase in inequality in the early stages of development and a reduction in inequality in subsequent periods. This was formulated using the Lewis

dual economy model. ${ }^{3}$ Kuznets argued that agricultural economies (i.e. developing countries) are initially relatively equal societies with low average income. As the economy develops, the population migrates to non-agricultural sectors, where average incomes are higher, as is inequality. Thus initially, inequality worsens because of the higher proportion of national income in the industrial sector and the higher proportion of profits in national income. The early benefits of economic growth go to those with control over capital and better education. In time, as more of the population move out of the traditional, rural, agricultural sector to the modern, urban, industrial sector and real wages in industry begin to rise, income inequality decreases. What Kuznets implied on the inequality-to-growth linkage was that there is a trade off: inequality is a short-term price worth paying for long-term economic development, and that growth would eventually lead mechanistically to poverty reduction through the "trickle down" effect.

There has been a wide range of research pursuing these questions (for review see Sumner $\&$ Tiwari, 2009). The sum of this is as follows: Economic growth can impact on inequality through various channels including modification to the distribution of resources across sectors, relative prices, factor rewards and factor endowments. However,

\footnotetext{
${ }^{3}$ Lewis, however, did not assume a rise in inequality to be inevitable.
} 
there are too many country specifics to make a generalisation and the quality and availability of inequality data constrain the ability to make definitive statements. ${ }^{4}$

If one focuses on the share of GNI to the poorest (the poorest $20 \%$ or poorest $40 \%$ ), the country group averages in LICs, LMICs and UMICs are thought-provoking. The pattern that emerges when one considers the data without India and without China is that the share of GNI to the poorest 20 percent or poorest 40 percent of the population declines as countries get better off, and carries on declining.

The share of GNI to the poorest 20 percent or 40 percent of the population is highest in LICs, and lowest in UMICs (without India in the LMICs and without China in the UMICs) (see Table 8). At the same time the share of GNI of the richest decile rises as a country moves from LICs to LMICs to UMIC (when China and India are excluded).

This and the "capture" of about half of GNI in the middle deciles (decile 5-decile 9) in LICs, LMICs and UMICs corroborates Palma's (2011) "homogeneous middles, heterogeneous tails" thesis.

In the top 20 countries where 90 percent of the world's poor live, only 15 of those 20 countries have two data points (see Table 2). In those countries, the share of GNI to the poorest four deciles is, in general, static or declining when 1990 and 2008 are compared (using nearest available survey data).

However, five of the 15 countries are experiencing an increased share of GNI to the poorest 40 percent by more than 2 percentage points (Pakistan, Kenya, Uganda, Ethiopia, Brazil and Nepal). In parallel, the share of the richest decile is static or rising in most countries, with more or less the same set of exceptions (Pakistan, Kenya, Ethiopia, Brazil and Nepal).

Palma (2011) noted that the share of GNI to those who are neither extremely poor (which he defines as the poorest four expenditure deciles), nor rich (defined as the richest expenditure decile), is surprisingly similar, at about 50 percent of GNI, regardless of where (and when) one looks at the distribution data (see Table 9).

In short, there is a remarkable capture of half of GNI by those deciles between the poor and the rich. This suggests that, as Palma (2011) argues, domestic politics is about a contest for the remaining 50 percent of GNI between the very rich and the very poor.

\footnotetext{
${ }^{4}$ Deininger and Squire (1998: p. 279) note that the failure to find the Kuznets curve relationship overall does not mean it does not exist for individual countries: In 4 countries of their 49 country sample the Kuznets hypothesis was supported.
} 
Palma (2011) argued that, in light of the observation that the share of GNI of those people in deciles D5-D9 is generally half of national income, the "middle classes" should be renamed the "median classes":

Basically, it seems that a schoolteacher, a junior or mid-level civil servant, a young professional (other than economics graduates working in financial markets), a skilled worker, middle-manager or a taxi driver who owns his or her own car, all tend to earn the same income across the world - as long as their incomes are normalized by the income per capita of the respective country. (Palma, 2011: p. 102)

It is worth remembering, as noted above, that the amount of redistribution required to end extreme (\$1.25/day) poverty can be quite low in some middle-income countries.

Ravallion (2010) estimated the necessary marginal tax rates (MTRs) on the "rich" (those earning more than \$13/day) in order to end poverty in each country. Ravallion's data suggests that the MTRs necessary to end poverty are high in many of the "new MICs" (in contrast, many "old" MICs would require MTRs of under 10 percent to end poverty). This is particularly due to large populations of poor relative to the number of "rich" people in many new MICs (see Table 9). ${ }^{5}$

If the scope for domestic taxes is insufficient, access to aid may still be important in MICs, for the near future at least (see review of recent "middle class" literature in Sumner, 2012). Further, Cardenas et al. (2011: 19) are sceptical of tax rises for the middle classes based on the attitudes expressed in the World Values Survey:

the status quo in many Latin American countries is a very low level of income taxation for the middle classes. Given their attitudes and political say, it is very unlikely that the expansion of the middle class will result in greater levels of personal income taxation. This is the main difference in tax structures compared to the developed world.

OECD (2011a) discusses in some considerable detail middle class preferences for the amount of income redistribution via fiscal policy, notably what middle class households gain and the quality of public services. ${ }^{6}$

\footnotetext{
${ }^{5}$ Soares et al. (2011) find that conditional cash transfers in Brazil, Mexico and Chile have cost less than 1 percent of GDP.

${ }^{6}$ In particular OECD (2011a) addresses what role the middle classes in Latin America play in shaping fiscal policy and redistribution, and the impact of fiscal policies on the middle classes. Other factors that determine preferences to redistribution are noted from the literature, including: personal experiences of social mobility (Piketty, 1995), national and regional cultural and social values (Alesina \& Giuliano, 2009), the extent of impacts of (higher) taxation on leisure consumption (Meltzer \& Richards, 1981), levels of university education (Daude \& Melguizo, 2010; Torgler, 2005), and attitudes to prevailing levels of meritocracy (Alesina \& Angeletos, 2005). It is also noted that support for redistribution is undermined by low
} 
In short, the capacity to redistribute and the preferences of the non-poor for redistributive policies may become increasingly important for poverty reduction in middle-income countries. However, if there is little support amongst the more secure middle classes for paying more taxes, such policies will be constrained by political economy factors. This will be made worse if the lower "middle millions" are only just above extreme poverty as the data suggests: The number of "non-poor" people in the world (here meaning those above \$2/day) has risen significantly since 1990, as a proportion of the population and in absolute numbers (see Table 10). There has been a particularly notable expansion between \$2-\$4/day and \$4-\$10/day. Across all developing countries the proportion of people in the $\$ 2-\$ 10$ group has risen from about a quarter to almost a half. When the data is analysed without China the rise is less pronounced but still significant. The rises are particularly noticeable in the new MIC group, but visible in the data across both LMIC and UMIC groups.

The absolute numbers of people in the $\$ 2-\$ 4$ range have risen from $700 \mathrm{~m}$ to $1.4 \mathrm{bn}$, and in the \$4-\$10 range from 400m to $1.1 \mathrm{bn}$, across developing countries between 1990 and 2008. The rises are less pronounced without China but still entail a near doubling in the number of people in both the $\$ 2-\$ 4 /$ day and $\$ 4-\$ 10 /$ day group; so that there are excluding China - about 2 billion people under \$2/day globally, 1 bn in the \$2-\$4 range, and $720 \mathrm{~m}$ in the $\$ 4-\$ 10$ range. In short, there will in the near future be about the same number of non-poor insecure people as poor people. The rises are, as noted above, particularly evident in the new MIC group but also cross both LMIC and UMIC groups.

As countries get richer in per capita income, on average individual taxes as a proportion of GDP rise (see Table 11) and aid declines in importance. This is in part due to the fact that as people's expenditures rise above $\$ 2 /$ day their consumption patterns change, resulting in an increasing exposure to indirect and sales taxes, and perhaps formal (and informal) payments for business licenses (although possibly not income taxes if they are in the informal sector). ${ }^{7}$ This has the potential to change perceptions of the relationship between the state and the individual.

Recent empirical evidence for this is provided by Devarajan et al. (2011: p. 15), who identify a positive relationship, significant at 1 percent, between the level of tax revenue and the extent of voice and accountability in a country (using Kaufmann governance indicators for voice and accountability); but argue that there is a threshold at 49 percent of GDP after which, with excessively high levels of taxation, the relationship is inverted. As the authors note (p. 15), "Since the tax-to-GDP ratio in most developing countries is below this level, one can assume that most of them are situated on the rising part of the

institutional capacity in tax administration, the quality of state services, and pessimistic views over social mobility (Gaviria, 2007; Torgler, 2005).

${ }^{7}$ IMF (2011: p. 25) estimates average sales taxes at end 2010 as 16 percent in LICs, 13 percent in LMICs and 15 percent in UMICs. 
relationship where increases in the level of taxation are associated with more accountability." Interestingly, Devarajan et al. (2011: p. 13) also note that governance and secondary education have a strong association even after controlling for various variables. Further, Loayza et al., (2012) have linked the size of the "middle class" (which they define as the proportion of people earning more than US\$10 per capita) with more progressive social policy on health and education (higher spending) and improvements in the quality of governance (democratic participation and official corruption) and these impacts are more robust that higher GDP per capita.

Table 11 shows that, as average income rises, total tax as a proportion of GDP rises as does individual income tax and tax on goods and services (the latter of which is more significant as a percent of GDP at earlier stages of development according to the IMF data). And at the same time as average income rises, aid is becoming less and less significant as a proportion of GNI in new MICs. There is thus a shift from external funding in the form of aid towards non-aid and domestic sources from taxation; hypothetically, this implies a shift in accountability from state-to-donors to state-todomestic tax payers and/or natural resource incomes (see Brautigam et al., 2008; Moore, 2007)

\section{And the (Possible) Evolving Distribution of Global Poverty}

One position to take is that there is little need to worry about the poor in MICs because growth will end poverty in the near future. How reasonable is this argument? Conceptually, the poor in middle-income countries could be disconnected from a country's growth due to spatial inequality or remoteness. The poor may also be relatively voiceless in domestic governance structures and potentially discriminated against in public services and public spending allocations regionally. And intra-country migration may be hindered or constrained by cost and administrative regulations.

One way to explore the question is to estimate poverty in the future by different scenarios in order to assess if poverty in MICs will be easily addressed by growth in those countries which are currently LMICs. This can be done by drawing upon an approach originally taken by Moss and Leo (2011) and Karver et al. (2012), the latter of which estimate poverty levels for a range of indicators in 2030. The approach is to generate three different growth scenarios (which goes some way to recognising the range of possibilities).

An optimistic scenario assumes that between 2009 and 2020, average incomes will rise at the average annual growth rate of the Gross Domestic Product PPP per capita data in the IMF's (2012) World Economic Outlook (WEO), for the period 2009-2016 (2011-2016 data are projections). A moderate growth scenario assumes that from 2009 average incomes will grow at an average annual growth rate of the Gross Domestic Product (PPP) per capita for the period 2009-2016, minus 1 percent on the basis that this is the average 
error historically observed in IMF growth estimates/projections (as per empirical analysis of Aldenhoff, 2007). A pessimistic growth scenario assumes that, from 2009, average incomes will grow at half of the average annual growth rate of the Gross Domestic Product (PPP) per capita for the period 2009-2016.

These growth scenarios then generate, for each country, GDP PPP and GNI per capita forecasts for 2020. The former, GDP per capita PPP, can be used to estimate poverty in 2020 (although an assumption of static inequality must be made), and the latter, GNI per capita, can be used to estimate country classifications in 2020. And by taking the poverty and distribution survey data from PovcalNet (World Bank, 2012), and the 2020 population estimates from the UN (medium variant), it is possible to make an estimate of the number of poor people in 2020 in each country, as well as the poverty gap as a proportion of GDP (PPP\$ constant 2005 international \$).

Two essential caveats must be noted: First, such projections are an inherently imprecise exercise that merely illustrates possible future scenarios (See also discussion in Kanbur \& Sumner, 2011; Karver et al., 2012; and Kenny \& Williams, 2001). Second, the approach likely overstates poverty reduction in fast growing economies such as LMICs, because it assumes static inequality in countries that are rapidly growing (the discussion earlier suggests this is questionable).

Even so, the data suggests that $\$ 1.25$ and $\$ 2$ poverty in those countries that are currently MICs will remain half of all world poverty in 2020 (see Table 12). And given that some countries that are currently LICs will move into the LMIC category, this suggests the structure of world poverty will remain split between LICs and MICs (see Table 12). Geographically, the data suggests poverty will be increasingly focused in Sub-Saharan Africa. As GDP rises the cost of ending poverty as a proportion of domestic GDP will (likely) fall, and poverty will become increasingly about national distribution, with the potential exception of some countries in sub-Saharan Africa. The projections for 2020 show that the number of LICs in 2020 could be in the range of 24 to 30. In 2020, global poverty is estimated to be split evenly between countries that are currently LICs and countries that are currently LMICs (in 2010). However, geographically, poverty is estimated to be focused in sub-Saharan Africa with 60-80\% of world poverty in that region of the world and the remainder largely in South Asia.

This suggests that even if inequality does not rise, poverty will remain an issue for MICs, and of course as noted a number of the countries that are currently LICs will be MICs by 2020 too. If inequality does rise in countries growing fast and attaining middle-income status it is likely these projections understate the proportion of world poverty in MICs in 2020, as higher levels of inequality will reduce the growth elasticity of poverty. It also suggests the cost to end poverty will be minimal for those countries that are currently LMICs and UMICs as a percentage of GDP (see Table 12). The estimated cost in those countries that are currently LICs of ending $\$ 1.25$ poverty would be $3.5 \%-8.0 \%$ of GDP 
and for $\$ 2$ poverty would be $11.6 \%-24.5 \%$ percent of GDP in 2020 . This suggests that for a relatively small number of countries (24-30 LICs), external support for poverty reduction will remain essential. However, in those countries that are currently LMICs the cost of ending $\$ 1.25$ poverty is estimated to be $0.2 \%-0.6 \%$ of GDP in 2020 and the cost of ending $\$ 2$ poverty in 2020 is estimated to be $0.9 \%$ to $2.7 \%$ of GDP. The projections suggest that global poverty in 2020 will be concentrated in a mix of countries that are currently LICs and LMICs. However, at least half of the world's poor might live in countries where the cost of ending $\$ 1.25$ poverty is highly negligible and two-thirds of the world's poor might live in countries where the cost of ending $\$ 2$ poverty is in a range that might be domestically manageable (1-3\% of GDP) by 2020.

\section{Conclusions}

In 1990, approximately 90 percent of the world's poor people (by both $\$ 1.25$ and $\$ 2$ international poverty lines) lived in low-income countries, where the average PPP per capita income was barely above the higher ( $\$ 2 /$ day) international poverty line - and thus addressing global poverty was framed largely around international redistribution via aid. In 2008, 70-80 percent of the world's poor people (respectively, by the $\$ 1.25$ and $\$ 2$ international poverty lines) lived in middle-income countries. In the LMIC group, the average PPP per capita income for the group was approximately five times the higher international poverty line.

In short, two things have happened: First, many countries have shifted to LMIC status and it is this shift, particularly of a few populous countries, that is a key factor causing the new "majority" of the world's poor to reside in the MICs. Second, while currently average income in many MICs is still way below that of the advanced countries, over time the cost of ending poverty is falling as a proportion of their national GDP to levels where domestic resources might be available to deal with poverty and this raises the question of whether "global poverty" requires reframing as a national distribution issue in a world of fewer and fewer aid dependent countries, either now or at some point in the foreseeable future.

Using absolute income thresholds for country classification mean income growth will always imply a transition of the poor from LICs to MICs, unless poverty falls drastically in absolute numbers during the transition. It depends on the country and the growth experience. It is likely that different countries are experiencing different trajectories based on the evolution of population growth, income growth, inequality and the poverty gap. One might suggest that there are two stylised groups of country evident if one considers a matrix of $2 \times 2$ with "equitable growth" (here defined as - at a minimum - the incomes of the poor rising in line with average income) and the "poverty gap" as the key variables. 
Group 1 countries are those with healthy and relatively equitable growth, and a low poverty gap as a percentage of GDP. In this group, the costs of poverty reduction are within domestic financial capacity. Group 2 countries are those with more unequal growth and larger poverty gaps; which may attain MIC status in terms of mean income but do not yet have the domestic financial fiscal means to address poverty despite higher average incomes. For Group 1, the issue is one of domestic redistribution. Group 1 may be largely concentrated in parts of Latin America and East Asia. Group 2 may include India and much of sub-Saharan Africa. Looking ahead to 2020, as average incomes rise, more and more of the world's poor will live in Group 1 countries, and poverty will increasingly become a matter of national inequality.

This might imply that a fundamental reframing of global poverty is approaching; "traditional aid" (meaning resource transfer) is of limited relevance, and the core variable to explain global poverty is increasingly national distribution and thus national political economy. 


\section{References}

Aldenhoff, F.O. (2007). Are Economic Forecasts of the International Monetary Fund Politically Biased? A Public Choice Analysis. Review of International Organizations 2(3), 239-60.

Alkire, S., Roche, J., Santos, E., \& Seth, S. (2011) Multidimensional Poverty 2011. Oxford: OPHI.

Alesina, A., \& Angeletos, G. M. (2005). Fairness and Redistribution. American Economic Review 95(4), 960-80.

Alesina, A., \& Giuliano, P. (2009). Preferences for Redistribution. NBER Working Paper 14825. New York: National Bureau of Economic Research.

Besley, T. \& Cord, L. (Eds). (2007). Delivering on the Promise of Pro-Poor Growth: Insights and Lessons from Country Experiences. Basingstoke: Palgrave Macmillan.

Brautigam, D., Fjeldstad, O-H., \& Moore, M. (2008). Taxation and State Building in Developing Countries. Cambridge: Cambridge University Press.

Bruno, M., Ravallion, M., \& Squire, L. (1998). Equity and Growth in Developing Countries: Old and New Perspectives on the Policy Issues. In V. Tanzi and K. Chu (Eds). Income Distribution and High Quality Growth. Cambridge, MA: MIT Press.

Cardenas, M., Kharas, H., \& Heneo, C. (2011). Latin America's Global Middle Class. Brookings Institution Paper. Washington DC: Brookings Institution.

Chandy, L. \& Gertz, G. (2011). Poverty in Numbers: The Changing State of Global Poverty from 2005 to 2015. Policy Brief 2011-01. Washington, DC: Global Economy and Development at Brookings, The Brookings Institution.

Chen, S., \& Ravallion, M. (2012). An Update to the World Bank's Estimates of Consumption Poverty in the Developing World. Washington, DC: World Bank.

Chen, S. \& Ravallion, M. (2008). The Developing World is Poorer Than Thought but No Less Successful in the Fight Against Poverty. Policy Research Working Paper 4703. Washington, DC: World Bank (also published in 2010 in Quarterly Journal of Economics 125(4), 1577-1625).

Daude, C., \& Melguizo, A. (2010). Taxation and More Representation? On Fiscal Policy, Social Mobility and Democracy in Latin America. Working Paper 294. Paris: OECD Development Center.

Deaton, A. (2011). Measuring Development: Different Data, Different Conclusions. Paper presented at the $8^{\text {th }} A F D-E U D N$ Conference. Paris: EUDN.

Deaton, A. (2010). Price Indexes, Inequality, and the Measurement of World Poverty. American Economic Review 100(1), 5-34.

Deaton, A., \& Heston, A. (2010). Understanding PPPs and PPP-based National Accounts. American Economic Journal 2(4), 1-35.

Deininger, K. and Squire, L. (1998). New Ways of Looking at Old Issues: Inequality and Growth. Journal of Development Economics 57(2), 259-87.

Dollar, D. \& Kraay A. (2002). Growth is Good for the Poor. Journal of Economic Growth 7, 195-225. 
Devarajan, S., Ehrhart, H., Minh Le, T. \& Raballand, G. (2011). Direct Redistribution, Taxation, and Accountability in Oil-Rich Economies: A Proposal. CGD Working Paper. Washington DC: Center for Global Development.

Fields, G. (2001). Distribution and Development: A New Look at the Developing World. Cambridge, MA: MIT Press.

Fischer, A.M. (2010) 'Towards Genuine Universalism within Contemporary Development Policy', IDS Bulletin 41, 36-44

Gallup, J., Radelet, S., \& Warner, A. (1999). Economic Growth and the Income of the Poor, Consulting Assistance on Economic Reform II. Discussion Paper 36. Harvard, MA: Harvard Institute of International Development.

Gaviria, A. (2007). Social Mobility and Preferences for Redistribution in Latin America. Economia 8(1), 55-88.

Gentilini, U., \& Sumner A. (2012). What do National Poverty Lines Tell Us about Global Poverty? IDS Working Paper. Brighton: IDS.

Glassman, A., Duran, D., \& Sumner, A. (2011). Global Health and the New Bottom Billion: What Do Shifts in Global Poverty and the Global Disease Burden Mean for GAVI and the Global Fund? CGD Working Paper. Washington, DC: Center for Global Development.

Grimm, M., Klasen, S., \& McKay, A. (2007). Determinants of Pro-poor Growth: Analytical Issues and Findings from Country Cases. Basingstoke: Palgrave Macmillan.

IMF (2011). Revenue Mobilization in Developing Countries. Washington DC: IMF.

IMF (2012). World Economic Outlook Database, Washington, DC: IMF.

Kanbur, R., \& Sumner, A. (2011). Poor Countries or Poor People? Development Assistance and the New Geography of Global Poverty. Working Paper 2011-08. Ithaca, NY: Charles H. Dyson School of Applied Economics and Management, Cornell University.

Kanbur, R., \& Mukherjee, D. (2007). Poverty, Relative to the Ability to Eradicate It: An Index of Poverty Reduction Failure. Working Paper 2007-02. Ithaca, NY: Charles H. Dyson School of Applied Economics and Management, Cornell University.

Karver, J., Kenny, C., \& Sumner, A. (2012). MDGs 2.0: What Goals, Targets and Timeframe? CGD Working Paper. Washington, DC: Center for Global Development.

Kenny, C., \& Williams, D. (2001). What do we know about economic growth: or why don't we know very much? World Development 29(1), 1-23.

Klasen, S. (2010) Levels and Trends in Absolute Poverty in the World: What We Know and What We Don't', paper prepared for the International Association for Research in Income and Wealth, St. Gallen, Switzerland, August 22-28

Kraay, A. (2004). When is Growth Pro-Poor? Cross-Country Evidence. World Bank Working Paper 3225. Washington, DC: World Bank.

Kuznets S. (1955). Economic growth and income inequality. American Economic Review 45(1), 1-28. Kuznets S. (1963). Quantitative aspects of the economic growth of 
nations: VIII, Distribution and income by size. Economic development and cultural change (11) 2, 1-80.

Loayza N., Rigolini, J., \& Llorente, G., (2012) Do Middle Classes Bring Institutional Reforms? World Bank Working Paper 6015. Washington, DC: World Bank.

Moore, M. (2007). How Does Taxation Effect the Quality of Governance? IDS Working Paper 280. Brighton: IDS.

Mosley, P. (2004). Severe Poverty and Growth: A Macro-Micro Analysis. Chronic Poverty Research Centre Working Paper 51. Manchester, UK: CPRC.

Mosley, P., Hudson, J., \& Verschoor, A. (2004). Aid, Poverty Reduction and the New Conditionality. Economic Journal 114, 214-43.

Moss, T., \& Leo, B. (2011). IDA at 65: Heading Toward Retirement or a Fragile Lease on Life? CGD Working Paper 246, Washington, DC: Center for Global Development.

OECD (2011a). Latin American Economic Outlook: How Middle Class is Latin America? Paris: OECD.

OECD (2011b). Ensuring Fragile States Are Not Left Behind: 2011 Factsheet on Resource Flows in Fragile States. Paris: OECD.

Palma, J.G. (2011). Homogeneous Middles vs. Heterogeneous Tails, and the End of the 'Inverted-U': It's All About the Share of the Rich. Development and Change 42(1): $87-153$.

Piketty, T. (1995). Social Mobility and Redistributive Politics. Quarterly Journal of Economics 110(3), 551-84.

Ravallion, M. (2010). Do Poorer Countries Have Less Capacity for Redistribution? Journal of Globalization and Development 1(2), 1-8.

Ravallion, M. (2001). Growth, Inequality and Poverty: Looking Behind the Averages. World Development 29(11), 1803-15.

Roemer M., \& Gugerty, M. (1997). Does Economic Growth Reduce Poverty? Consulting Assistance on Economic Reform II. Discussion Paper 4. Harvard: Harvard Institute of International Development.

Seers, D. (1963). The Limitations of the Special Case. Bulletin of the Oxford Institute of Economics and Statistics 25(2), 77-98. Reprinted in K. Martin and J. Knapp (Eds.) (1967). The Teaching of Development Economics: Its Position in the Present State of Knowledge. London: Frank Cass, 1-27.

Soares, S., Guerreiro Osorio, R., Veras Soares, F., Medeiros, M., \& Zepeda, E. (2011). Conditional Cash Transfers In Brazil, Chile And Mexico: Impacts Upon Inequality. Washington, DC: Carnegie Endowment for International Peace.

Son, H., \& Kakwani, N. (2003). Poverty Reduction: Do Initial Conditions Matter? Mimeograph. Washington DC: World Bank.

Sumner, A., \& Tiwari, M. (2009). After 2015: International Development Policy at a Crossroads, Basingstoke, Palgrave MacMillan.

Sumner, A. (2010) Global Poverty and the New Bottom Billion. IDS Working Paper. Brighton: IDS. 
Sumner, A. (2012). Where do the Poor Live? World Development 40(5), 865-877.

Torgler, B. (2005). Tax Morale in Latin America. Public Choice 122(1/2), 133-57.

World Bank (2012) PovcalNet. Accessed 1 April 2012.

<http://iresearch.worldbank.org/PovcalNet/index.htm>

World Bank (2011) World Development Indicators. Washington, DC: World Bank. 
Table 1. Estimates of the distribution of global poverty and poverty incidence, $\$ 1.25$ and $\$ 2,1990$ and 2008

\begin{tabular}{|c|c|c|c|c|c|c|}
\hline \multirow[t]{2}{*}{2008} & \multicolumn{3}{|c|}{$\$ 1.25$ poverty line } & \multicolumn{3}{|c|}{$\$ 2$ poverty line } \\
\hline & $\begin{array}{l}\text { Millions of } \\
\text { people }\end{array}$ & $\begin{array}{l}\% \text { world's } \\
\text { poor }\end{array}$ & $\begin{array}{l}\text { Poverty incidence }(\% \\
\text { pop.) }\end{array}$ & $\begin{array}{l}\text { Millions of } \\
\text { people }\end{array}$ & $\begin{array}{l}\% \text { world's } \\
\text { poor }\end{array}$ & $\begin{array}{l}\text { Poverty incidence }(\% \\
\text { pop.) }\end{array}$ \\
\hline East Asia and Pacific & 265.4 & 21.5 & 14.3 & 614.3 & 26.1 & 33.2 \\
\hline Europe and Central Asia & 2.1 & 0.2 & 0.5 & 9.9 & 0.4 & 2.4 \\
\hline $\begin{array}{l}\text { Latin American and the } \\
\text { Caribbean }\end{array}$ & 35.3 & 2.9 & 6.9 & 67.4 & 2.9 & 13.1 \\
\hline $\begin{array}{l}\text { Middle East and North } \\
\text { Africa }\end{array}$ & 8.5 & 0.7 & 2.7 & 43.8 & 1.9 & 13.9 \\
\hline South Asia & 546.5 & 44.3 & 36.0 & $1,074.7$ & 45.6 & 70.9 \\
\hline Sub-Saharan Africa & 376.0 & 30.5 & 47.5 & 547.5 & 23.2 & 69.2 \\
\hline LICs & 316.7 & 25.7 & 48.5 & 486.3 & 20.6 & 74.4 \\
\hline LMICs & 711.6 & 57.7 & 30.2 & $1,394.5$ & 59.2 & 59.1 \\
\hline LMICs minus India & 285.6 & 23.1 & 23.4 & 569.4 & 24.2 & 46.7 \\
\hline UMICs & 205.5 & 16.7 & 8.7 & 476.6 & 20.2 & 20.3 \\
\hline UMICs minus China & 32.5 & 2.6 & 3.2 & 82.3 & 3.5 & 8.0 \\
\hline $\begin{array}{l}45 \text { fragile states (OECD } \\
\text { 2011) }\end{array}$ & 412.3 & 33.4 & 40.3 & 684.0 & 29.0 & 66.9 \\
\hline Least developed countries & 324.0 & 26.3 & 46.4 & 505.0 & 21.4 & 72.2 \\
\hline $\begin{array}{l}\text { Quartile } 1 \text { (poorest GDP } \\
\text { PPP pc) }\end{array}$ & 454.6 & 36.8 & 45.6 & 680.8 & 28.9 & 68.3 \\
\hline Total & $1,233.8$ & $100.0 \%$ & $22.8 \%$ & $2,357.5$ & $100.0 \%$ & $43.6 \%$ \\
\hline
\end{tabular}




\section{Table 1 continued}

\begin{tabular}{|c|c|c|c|c|c|c|}
\hline \multirow[t]{2}{*}{1990} & \multicolumn{3}{|c|}{$\$ 1.25$ poverty line } & \multicolumn{3}{|c|}{$\$ 2$ poverty line } \\
\hline & $\begin{array}{l}\text { Millions of } \\
\text { people }\end{array}$ & $\begin{array}{l}\% \text { world's } \\
\text { poor }\end{array}$ & $\begin{array}{l}\text { Poverty incidence ( } \% \\
\text { pop.) }\end{array}$ & $\begin{array}{l}\text { Millions of } \\
\text { people }\end{array}$ & $\begin{array}{l}\% \text { world's } \\
\text { poor }\end{array}$ & $\begin{array}{l}\text { Poverty incidence ( } \% \\
\text { pop.) }\end{array}$ \\
\hline East Asia and Pacific & 863.8 & 47.9 & 56.3 & $1,242.8$ & 46.0 & 80.9 \\
\hline Europe and Central Asia & 8.6 & 0.5 & 1.9 & 30.8 & 1.1 & 6.9 \\
\hline $\begin{array}{l}\text { Latin American and the } \\
\text { Caribbean }\end{array}$ & 45.4 & 2.5 & 12.6 & 80.0 & 3.0 & 22.2 \\
\hline $\begin{array}{l}\text { Middle East and North } \\
\text { Africa }\end{array}$ & 12.7 & 0.7 & 5.8 & 51.8 & 1.9 & 23.6 \\
\hline South Asia & 599.3 & 33.2 & 54.0 & 928.6 & 34.3 & 83.7 \\
\hline Sub-Saharan Africa & 274.7 & 15.2 & 56.6 & 369.4 & 13.7 & 76.1 \\
\hline LICs & $1,694.7$ & 93.9 & 56.9 & $2,465.4$ & 91.2 & 82.8 \\
\hline $\begin{array}{l}\text { Quartile } 1 \text { (poorest GDP } \\
\text { PPP pc) }\end{array}$ & $1,587.2$ & 88.0 & 58.5 & $2,281.3$ & 84.4 & 84.1 \\
\hline Total & $1,804.6$ & $100.0 \%$ & $22.8 \%$ & $2,703.6$ & $100.0 \%$ & $65.0 \%$ \\
\hline
\end{tabular}

Source: Data processed from PovcalNet (World Bank, 2012). Note: PINCIs = Pakistan, India, Nigeria, China and Indonesia. Fragile States $=45$ countries in OECD (2011b). Q1 by GDP pc PPP $=$ poorest quartile of countries. 
Table 2. Top 20 poor countries (by number of $\$ 1.25 /$ day poor people), and indicators of poverty and income per capita (countries transitioning from LIC to MIC since 1990 are highlighted)

\begin{tabular}{|c|c|c|c|c|c|c|c|c|c|c|}
\hline & \multirow[t]{2}{*}{$\begin{array}{l}\% \text { World } \\
\$ 1.25 \\
\text { Poor, } 2008\end{array}$} & \multirow[t]{2}{*}{$\begin{array}{l}\% \text { World } \\
\$ 2 \text { Poor, } \\
2008\end{array}$} & \multirow[t]{2}{*}{$\begin{array}{l}\text { Cost of ending } \$ 1.25 \\
\text { poverty }(\% \text { GDP) } \\
\text { PPP, } 2008 \text { (constant } \\
2005 \text { int'l \$) }\end{array}$} & \multirow[t]{2}{*}{$\begin{array}{l}\text { Cost of ending } \$ 2 \\
\text { poverty }(\% \text { GDP) } \\
\text { PPP, } 2008 \text { (constant } \\
2005 \text { int'l } \$)\end{array}$} & \multicolumn{2}{|c|}{$\begin{array}{l}\text { Share of GNI to } \\
\text { poorest } 40 \%\end{array}$} & \multicolumn{2}{|c|}{$\begin{array}{l}\text { Country } \\
\text { classification } \\
\text { (based on data for } \\
\text { calendar year) }\end{array}$} & \multicolumn{2}{|c|}{$\begin{array}{l}\text { GDP pc/day } \\
(\mathrm{PPP}, \text { constant } \\
2005 \$)\end{array}$} \\
\hline & & & & & 1990 & 2008 & 1990 & 2009 & 1990 & 2009 \\
\hline 1. India & 34.5 & 35.0 & 1.5 & 7.1 & 21.4 & 20.9 & LIC & LMIC & 3.4 & 8.2 \\
\hline 2. China & 14.0 & 16.7 & 0.3 & 1.3 & 20.2 & 14.8 & LIC & UMIC & 3.0 & 17.0 \\
\hline 3. Nigeria & 8.1 & 5.4 & 7.6 & 18.4 & 12.8 & 12.7 & LIC & LMIC & 3.9 & 5.6 \\
\hline 4. Bangladesh & 6.0 & 5.3 & 4.6 & 19.1 & 23.3 & 21.3 & LIC & LIC & 2.0 & 3.9 \\
\hline 5. DRC & 4.5 & 2.6 & 79.4 & 165.5 & $\mathrm{n} / \mathrm{a}$ & 14.7 & LIC & LIC & 1.7 & 0.8 \\
\hline 6. Indonesia & 4.2 & 5.2 & 0.6 & 3.5 & 22.6 & 20.4 & LIC & LMIC & 5.5 & 10.1 \\
\hline 7. Pakistan* & 2.3 & 5.2 & 0.7 & 5.6 & 20.3 & 22.5 & LIC & LMIC & 4.4 & 6.5 \\
\hline 8. Tanzania & 1.4 & 1.6 & 10.7 & 29.2 & 19.6 & 17.9 & LIC & LIC & 2.4 & 3.4 \\
\hline 9. Philippines & 1.3 & 1.6 & 0.6 & 3.1 & 15.2 & 15.4 & LMIC & LMIC & 7.0 & 9.2 \\
\hline 10. Kenya & 1.2 & 1.1 & 4.9 & 15.2 & 10.1 & 13.5 & LIC & LIC & 3.9 & 3.9 \\
\hline 11. Vietnam & 1.1 & 1.6 & 0.7 & 3.8 & 19.2 & 18.9 & LIC & LMIC & 2.5 & 7.5 \\
\hline 12. Uganda & 1.1 & 0.9 & 6.5 & 21.6 & 14.2 & 15.5 & LIC & LIC & 1.5 & 3.1 \\
\hline 13. Madagascar & 1.1 & 0.7 & 15.5 & 38.7 & 14.4 & 14.9 & LIC & LIC & 2.8 & 2.4 \\
\hline 14. Mozambique & 1.0 & 0.8 & 14.8 & 40.4 & $\mathrm{n} / \mathrm{a}$ & 14.7 & LIC & LIC & 1.1 & 2.2 \\
\hline 15. Ethiopia* & 0.9 & 1.8 & 1.6 & 13.8 & 18.0 & 22.5 & LIC & LIC & 1.5 & 2.4 \\
\hline 16. Brazil & 0.8 & 0.9 & 0.2 & 0.4 & 7.5 & 10.0 & UMIC & UMIC & 19.7 & 25.9 \\
\hline 17. Angola & 0.8 & 0.5 & 2.6 & 5.8 & $\mathrm{n} / \mathrm{a}$ & 7.7 & LIC & LMIC & 9.0 & 14.8 \\
\hline 18. Malawi & 0.8 & 0.6 & 18.1 & 49.7 & $\mathrm{n} / \mathrm{a}$ & 17.8 & LIC & LIC & 1.6 & 2.1 \\
\hline 19. Nepal & 0.8 & 0.8 & 4.0 & 17.5 & 19.6 & 20.4 & LIC & LIC & 1.9 & 2.9 \\
\hline 20. Sudan* & 0.7 & 0.8 & 1.3 & 5.9 & $\mathrm{n} / \mathrm{a}$ & 18.5 & LIC & LMIC & 2.8 & 5.4 \\
\hline
\end{tabular}

Source: Data processed from PovcalNet (World Bank, 2012) and WDI (2011). Note: * = The poverty data listed in PovcalNet (World Bank, 2012) for these countries in 2008 appears lower than one might expect suggesting caution (see also discussion in Sumner 2012b) and for rates by national poverty lines see Gentilini and Sumner (2012). 
Table 3. GDP pc PPP (constant 2005 \$): Relative position of countries by quartiles (countries by 1990 and 2008 position, $\mathrm{Q} 1$ = poorest)

\begin{tabular}{lllll}
\hline & 1990 & & & \\
\cline { 2 - 5 } 2008 & Q4 & Q3 & Q2 & Q1 $(* *)$ \\
\hline Q4 & 40 & 3 & 1 & 0 \\
Q3 & 2 & 33 & 5 & 0 \\
Q2 $(*)(* *)$ & 0 & 5 & 30 & 7 \\
Q1 (poorest) & 0 & 0 & 3 & 35 \\
\hline
\end{tabular}

Source: Processed from WDI (2011). Note: $*=$ China; $* *=$ India.

Table 4. Distribution of global poverty (\$1.25 and \$2) by GDP pc (PPP 2005 constant \$) quartiles

\begin{tabular}{lllll}
\hline & $\$ 1.25$ & & $\$ 2$ & \\
\cline { 2 - 5 } & 1990 & 2008 & 1990 & 2008 \\
\cline { 2 - 5 } Q4 & 0.0 & 0.0 & 0.0 & 0.0 \\
Q3 & 2.5 & 2.5 & 3.8 & 3.4 \\
Q2 & 8.9 & $60.6\left(^{*}\right)(* *)$ & 11.1 & $67.8\left(^{*}\right)\left(^{* *}\right)$ \\
Q1 (poorest) & $88.5\left(^{*}\right)(* *)$ & 36.8 & $85.1\left(^{*}\right)(* *)$ & 28.9 \\
\hline
\end{tabular}

Source: Processed from PovcalNet (World Bank, 2012) and WDI (2011). Note: * = China; ** = India. 
Table 5. Selected Indicators of Development by Country Groupings, 2009 (population weighted)

\begin{tabular}{|c|c|c|c|c|c|c|}
\hline & \multicolumn{2}{|c|}{ World Bank classifications } & \multicolumn{3}{|c|}{ Other classifications } & \multirow[b]{2}{*}{$\begin{array}{l}\text { Q1 GDP pc PPP } \\
(45)\end{array}$} \\
\hline & LICs (35) & LMICs (56) & $\begin{array}{l}\text { LMICs minus } \\
\text { India }\end{array}$ & $\begin{array}{l}\text { FCAS } \\
(45)\end{array}$ & $\begin{array}{l}\mathrm{LDC} \\
(48)\end{array}$ & \\
\hline GNI per capita/day (Atlas, current \$) & 1.3 & 3.9 & 4.6 & 2.7 & 5.8 & 2.7 \\
\hline GNI pc/day (PPP, current \$) & 3.1 & 9.1 & 9.3 & 5.1 & 3.8 & 4.0 \\
\hline GDP pc/day (PPP, 2005 constant \$) & 2.9 & 8.5 & 8.8 & 4.7 & 3.5 & 3.6 \\
\hline Poverty (\% pop., $\$ 1.25,2008)$ & 48.5 & 30.2 & 23.4 & 40.3 & 46.4 & 48.1 \\
\hline Net ODA as $\%$ of GNI * & 12.6 & 1.0 & 1.8 & 7.1 & 11.1 & 9.6 \\
\hline Net ODA/Gross capital formation * & 53.1 & 3.5 & 6.3 & 32.8 & 41.2 & 36.2 \\
\hline Total reserves in months of imports & 4.5 & 8.0 & 6.3 & 3.8 & 3.4 & 4.1 \\
\hline GDP in agriculture (\%) & 30.8 & 17.3 & 16.8 & 20.2 & 26.6 & 23.0 \\
\hline Urbanisation ( $\%$ population) & 27.9 & 39.2 & 47.6 & 34.9 & 28.8 & 32.4 \\
\hline Gross domestic savings as $\%$ GDP & 9.1 & 24.4 & 17.3 & 8.0 & 10.0 & 8.1 \\
\hline Agricultural raw materials as $\%$ exports * & 9.7 & 1.9 & 2.6 & 3.8 & 4.4 & 4.6 \\
\hline Ores and metal as $\%$ exports $*$ & 7.4 & 5.9 & 5.5 & 2.0 & 5.4 & 4.3 \\
\hline
\end{tabular}

Source: Data processed from WDI (World Bank, 2011b) and PovcalNet (World Bank, 2012). Note: Some indicators have weaker coverage for FCAS, LDCs and Q1 countries - see data coverage below. FCAS = 45 Fragile and Conflict Affected States of OECD (2011b); LDC = Least Developed Countries Group; Q1 GDP pc PPP = poorest quartile of countries by GDP per capita PPP. Note: * A high degree of dispersion within country groupings suggests some caution is required in interpretation of these indicators. 
Table 6. Economic indicators as \% OECD HICs, 2009 (population weighted)

\begin{tabular}{|c|c|c|c|c|c|c|c|}
\hline & \multicolumn{2}{|c|}{ World Bank classifications } & \multicolumn{4}{|c|}{ Other classifications } & \multirow[t]{2}{*}{ HICs } \\
\hline & LICs (35) & LMICs (56) & $\begin{array}{l}\text { LMICs } \\
\text { minus India }\end{array}$ & $\begin{array}{l}\text { FCAS } \\
(45)\end{array}$ & $\begin{array}{l}\text { LDC } \\
(48)\end{array}$ & $\begin{array}{l}\text { Q1 GDP pc } \\
\text { PPP } \\
\text { (45) }\end{array}$ & \\
\hline GNI per capita/day (Atlas, current \$) & 1.2 & 3.7 & 4.3 & 2.6 & 5.5 & 2.5 & 100.0 \\
\hline GNI pc/day (PPP, current \$) & 3.1 & 9.1 & 9.2 & 5.2 & 3.9 & 4.0 & 100.0 \\
\hline GDP pc/day (PPP, const. \$) & 3.2 & 9.5 & 9.8 & 5.3 & 4.0 & 4.1 & 100.0 \\
\hline Total reserves in months of imports & 104.7 & 186.0 & 146.5 & 78.1 & 69.0 & 83.5 & 100.0 \\
\hline GDP in agriculture ( $\%)$ & $2,008.9$ & $1,127.9$ & $1,095.5$ & $1,361.6$ & $1,796.7$ & $1,549.2$ & 100.0 \\
\hline Urbanisation ( $\%$ population) & 36.2 & 50.9 & 61.8 & 45.2 & 37.3 & 42.0 & 100.0 \\
\hline Gross domestic savings as $\%$ GDP & 50.8 & 136.3 & 96.6 & 43.1 & 53.7 & 43.6 & 100.0 \\
\hline Agricultural raw materials as $\%$ exports * & 646.7 & 126.7 & 173.3 & 261.0 & 295.6 & 309.6 & 100.0 \\
\hline Ores and metal as $\%$ exports $*$ & 205.6 & 163.9 & 152.8 & 132.6 & 366.8 & 288.8 & 100.0 \\
\hline
\end{tabular}

Sources: Data processed from WDI (World Bank, 2011b). Note: $*$ A high degree of dispersion within country groupings suggests some caution is required in interpretation of these indicators. 
Table 7. Estimates of the total poverty gap as \% GDP, PPP\$ constant 2005 international $\$$ ) by $\$ 1.25$ and $\$ 2$ poverty line in $2008 / 9$

\begin{tabular}{lllll}
\hline & \multicolumn{2}{l}{$\begin{array}{l}\text { Total poverty gap as } \\
\text { \% GDP PPP }\end{array}$} & \multicolumn{2}{l}{$\begin{array}{l}\text { Distribution of world } \\
\text { poverty (\%) }\end{array}$} \\
\cline { 2 - 5 } & $\mathbf{\$ 1 . 2 5}$ & $\mathbf{\$ 2}$ & $\mathbf{\$ 1 . 2 5}$ & $\mathbf{\$ 2}$ \\
\cline { 2 - 5 } LICs & 8.4 & 25.4 & 25.7 & 20.6 \\
LMICs & 1.3 & 5.5 & 57.7 & 59.2 \\
UMICs & 0.2 & 0.6 & 16.7 & 20.2 \\
East Asia and Pacific & - & - & & \\
Eastern Europe and Central & 0.3 & 1.5 & 21.5 & 26.1 \\
Asia & 0.0 & 0.0 & 0.2 & 0.4 \\
Latin American and the & & & & \\
Caribbean & 0.2 & 0.4 & 2.9 & 2.9 \\
Middle East and North Africa & 0.0 & 0.4 & 0.7 & 1.9 \\
South Asia & 1.5 & 7.5 & 44.3 & 45.6 \\
Sub-Saharan Africa & 4.8 & 13.0 & 30.5 & 23.2 \\
\hline
\end{tabular}

Source: Data processed from PovcalNet (World Bank, 2012) and WDI (World Bank, 2011b). Note: Data presented as PPP\$, constant 2005 international \$ rather than current US\$ for comparison with 2020 estimates (see below). Poverty gap as \% GDP $=$ PG\%/100\% x $\$ 1.25$ per day x 365 x Population.

Table 8. Estimates of inequality, 2008, nearest available data (population weighted)

\begin{tabular}{llllll}
\hline & LICs & $\begin{array}{l}\text { LMICs } \\
\text { minus } \\
\text { India }\end{array}$ & $\begin{array}{l}\text { UMICs } \\
\text { minus } \\
\text { China }\end{array}$ & $\begin{array}{l}\text { All } \\
\text { LMICs }\end{array}$ & $\begin{array}{l}\text { All } \\
\text { UMICs }\end{array}$ \\
\cline { 2 - 6 } GNI to poorest 20\% (\%) & 7.9 & 7.3 & 4.9 & 8.0 & 4.9 \\
Poorest 4 deciles (D1-D4) & 19.5 & 18.4 & 13.9 & 19.6 & 14.5 \\
Middle 5 deciles (D9-D5) & 51.1 & 51.2 & 49.8 & 51.1 & 51.8 \\
Richest decile (D10) & 29.4 & 30.4 & 36.3 & 29.3 & 33.7 \\
\hline
\end{tabular}


Table 9. Estimates of share of GNI, 1990 and 2008 (nearest available data, population weighted)

\begin{tabular}{|c|c|c|}
\hline & \multicolumn{2}{|c|}{$\begin{array}{l}\text { GNI } \\
\text { Average share }(\%)\end{array}$} \\
\hline & 1990 & 2008 \\
\hline \multicolumn{3}{|l|}{ D10 (richest $10 \%$ ) } \\
\hline All developing countries & 27.6 & 31.0 \\
\hline LMICs (current group) & 24.8 & 29.3 \\
\hline LMICs (current group) minus India & 28.2 & 30.4 \\
\hline UMICs (current group) & 28.2 & 33.7 \\
\hline UMICs (current group) minus China & 35.0 & 36.3 \\
\hline New MICs & 30.6 & 31.0 \\
\hline \multicolumn{3}{|l|}{ D5-D9 (middle 50\%) } \\
\hline All developing countries & 51.9 & 50.8 \\
\hline LMICs (current group) & 52.2 & 51.1 \\
\hline LMICs (current group) minus India & 52.8 & 51.2 \\
\hline UMICs (current group) & 53.3 & 51.8 \\
\hline UMICs (current group) minus China & 50.5 & 49.8 \\
\hline New MICs & 50.9 & 50.4 \\
\hline \multicolumn{3}{|l|}{ D1-D4 (poorest 40\%) } \\
\hline All developing countries & 19.1 & 17.1 \\
\hline LMICs (current group) & 20.3 & 19.6 \\
\hline LMICs (current group) minus India & 19.0 & 18.4 \\
\hline UMICs (current group) & 18.5 & 14.5 \\
\hline UMICs (current group) minus China & 14.5 & 13.9 \\
\hline New MICs & 18.5 & 18.6 \\
\hline
\end{tabular}

Source: Data processed from PovcalNet (World Bank, 2012). 
Table 10. Estimates of population (\% population and millions) by region and expenditure groups, 1990 and 2008

\begin{tabular}{lllllll}
\hline & \multicolumn{3}{l}{ Less than $\$ 2$} & $\$ 2-\$ 4$ & & $\$ 4-\$ 10$ \\
\cline { 2 - 7 } & 1990 & 2008 & 1990 & 2008 & 1990 & 2008 \\
\cline { 2 - 7 } \% of population & & & & & & \\
LMICs (current group) & 73.3 & 59.1 & 18.3 & 27.2 & 6.7 & 11.0 \\
UMICs (current group) & 58.4 & 20.3 & 18.5 & 26.4 & 16.0 & 35.6 \\
China & 84.6 & 29.8 & 13.4 & 32.2 & 1.9 & 31.0 \\
India & 82.6 & 72.4 & 14.5 & 22.2 & 2.6 & 4.8 \\
New MICs & 78.5 & 64.9 & 15.3 & 25.0 & 4.8 & 8.1 \\
All developing countries & 67.1 & 43.9 & 17.2 & 25.9 & 10.9 & 21.1 \\
All developing countries & 60.2 & 48.6 & 18.7 & 23.9 & 14.4 & 17.9 \\
minus China & & & & & & \\
Millions & $1,256.7$ & $1,394.5$ & 314.2 & 641.0 & 114.3 & 260.3 \\
LMICs (current group) & $1,089.8$ & 476.6 & 345.5 & 621.0 & 298.2 & 838.3 \\
UMICs (current group) & 960.6 & 394.3 & 152.2 & 426.8 & 21.2 & 410.0 \\
China & 701.7 & 825.1 & 123.3 & 252.8 & 22.0 & 54.5 \\
India & $1,132.7$ & $1,266.4$ & 220.2 & 487.7 & 68.8 & 158.8 \\
New MICs & $2,696.3$ & $2,357.4$ & 690.7 & $1,391.4$ & 436.8 & $1,132.0$ \\
All developing countries & $1,735.8$ & $1,963.0$ & 538.5 & 964.6 & 415.6 & 722.0 \\
All developing countries & & & & & & \\
minus China & & & & &
\end{tabular}

Source: Data processed from PovcalNet (World Bank, 2012). Note: Data is population weighted. New MICs = graduation since 2000 .

Table 11. Total government taxes as \% GDP and ODA as \% GNI in 2009 or most recent year

\begin{tabular}{lllll}
\hline & LICs & LMIC & UMIC & $\begin{array}{l}\text { HIC } \\
\text { OECD }\end{array}$ \\
\cline { 2 - 5 } Total government taxes as \% GDP & 13.0 & 17.7 & 20.7 & 35.4 \\
Taxes on goods and services as \% & 5.0 & 6.1 & 7.1 & 11.2 \\
GDP & & & & \\
Individual income tax as \% GDP & 1.6 & 1.9 & 2.3 & 9.7 \\
ODA as \% GNI & 12.6 & 1.0 & 0.1 & 0.0 \\
\hline
\end{tabular}


Table 12. Estimates of the global distribution of poverty by country groups and estimates of the poverty gap as \% GDP, PPP\$ constant 2005 international \$) in 2008/9 and 2020 (e = estimate)

\begin{tabular}{|c|c|c|c|c|c|c|c|c|}
\hline \multirow{5}{*}{$\begin{array}{l}\text { Low income (current group) } \\
\text { Lower middle income (current } \\
\text { group) }\end{array}$} & \multicolumn{4}{|c|}{ Global distribution of poverty ( $\%$ world poverty) } & \multicolumn{4}{|c|}{ Poverty gap as \% GDP } \\
\hline & \multicolumn{2}{|l|}{$\$ 1.25$} & \multicolumn{2}{|l|}{$\$ 2$} & \multicolumn{2}{|l|}{$\$ 1.25$} & \multicolumn{2}{|l|}{$\$ 2$} \\
\hline & $2008 / 9$ & $2020 \mathrm{e}$ & $2008 / 9$ & $2020 \mathrm{e}$ & $2008 / 9$ & $2020 \mathrm{e}$ & $2008 / 9$ & $2020 \mathrm{e}$ \\
\hline & 25.7 & $45.8-51.8$ & 20.6 & $31.6-42.5$ & 8.4 & $3.5-8.0$ & 25.4 & $11.6-24.5$ \\
\hline & 57.7 & $42.6-49.6$ & 59.2 & $51.9-60.0$ & 1.3 & $0.2-0.6$ & 5.5 & $0.9-2.7$ \\
\hline $\begin{array}{l}\text { Upper middle income (current } \\
\text { group) }\end{array}$ & 16.7 & 3.6- 5.7 & 20.2 & $5.7-8.3$ & 0.2 & $0.0-0.0$ & 0.6 & $0.0-0.1$ \\
\hline Estimated remaining LICs in 2020 & - & $44.8-46.9$ & - & $32.5-33.8$ & - & $6.3-7.7$ & - & $19.3-23.7$ \\
\hline East Asia and Pacific & 21.5 & $2.7-5.8$ & 26.1 & $7.0-12.6$ & 0.3 & $0.0-0.0$ & 1.5 & $0.0-0.2$ \\
\hline Eastern Europe and Central Asia & 0.2 & $0.1-0.2$ & 0.4 & $0.3-0.4$ & 0.0 & $0.0-0.0$ & 0.0 & $0.0-0.0$ \\
\hline Latin America and the Caribbean & 2.9 & $5.2-7.2$ & 2.9 & $4.0-5.6$ & 0.2 & $0.1-0.2$ & 0.4 & $0.3-0.4$ \\
\hline Middle East and North Africa & 0.7 & $1.6-1.9$ & 1.9 & 2.6- 2.9 & 0.0 & $0.0-0.1$ & 0.4 & $0.2-0.4$ \\
\hline South Asia & 44.3 & $9.3-24.7$ & 45.6 & $27.9-41.2$ & 1.5 & $0.0-0.3$ & 7.5 & $0.5-2.5$ \\
\hline Sub-Saharan Africa & 30.5 & $62.6-79.0$ & 23.2 & $39.1-56.5$ & 4.8 & $2.7-5.6$ & 13.0 & $8.2-15.2$ \\
\hline
\end{tabular}

Sources: Data estimates derived by using method of Karver et al. (2012) and processed from PovcalNet (World Bank, 2012) and WEO (IMF, 2012), based on static inequality. 
ANNEX TABLE A1. Population coverage of indicators, 2009, (\% population of group covered)

\begin{tabular}{|c|c|c|c|c|c|}
\hline & LICs & MICs & FCAS & LDCs & $\begin{array}{l}\text { Q1 GDP PPP } \\
\text { pc }\end{array}$ \\
\hline Poverty at US\$1.25 and US\$2 (2008) & 83.5 & 98.0 & 99.4 & 85.4 & 89.9 \\
\hline GNI per capita (Atlas, current US\$) & 88.4 & 100.0 & 92.3 & 88.7 & 91.2 \\
\hline GNI per capita (PPP, current int'l \$) & 93.0 & 99.6 & 95.8 & 93.8 & 95.2 \\
\hline GDP per capita, PPP (constant 2005 international \$) & 88.0 & 99.7 & 95.8 & 93.8 & 95.2 \\
\hline Total reserves in months of imports & 63.2 & 96.0 & 65.0 & 48.5 & 59.8 \\
\hline Net ODA received ( $\%$ of GNI) & 86.8 & 96.0 & 92.8 & 89.5 & 91.8 \\
\hline Net ODA received ( $\%$ of gross capital formation) & 76.8 & 94.8 & 63.2 & 45.9 & 57.8 \\
\hline GDP in agriculture (\%) & 69.2 & 83.0 & 67.8 & 52.6 & 63.1 \\
\hline Urbanisation ( $\%$ population) & 100.0 & 100.0 & 100.0 & 100.0 & 100.0 \\
\hline Gross domestic savings as $\%$ GDP & 95.9 & 99.3 & 67.2 & 51.8 & 62.4 \\
\hline Agricultural raw materials exports as $\%$ exports & 78.2 & 98.6 & 54.4 & 32.9 & 47.7 \\
\hline Ores and metal exports as $\%$ merchandise exports & 78.2 & 98.6 & 54.4 & 33.0 & 47.8 \\
\hline
\end{tabular}

Sources: Data processed from WDI (World Bank, 2011b) and PovcalNet (World Bank, 2012). 